\title{
O Iluminismo do COVID-19 Confronta o Obscurantismo de Bolsonaro
}

Um dos maiores ataques ao conhecimento científico no Brasil teve início no governo Bolsonaro. Diante desse acontecimento, foi preciso que a comunidade acadêmica se mobilizasse, de imediato, para enfrentar e contestar as investidas provenientes dos defensores terraplanistas, daqueles que renunciam não apenas as formulações construídas com base na ciência, mas se apegam na ideia de que vale mais as interpretações convenientes, e não consensuais, do que o próprio fato. Por isso, vale mais os efeitos de uma Fake News, do que a base científica dos acontecimentos. Querem reescrever a história para adaptar o passado aos interesses políticos do momento presente, ou de eliminar o saber científico que não se ajuste às suas ideologias. $O$ governo está colocando em curso o controle total do sistema educacional, investindo, principalmente, contra as Ciências Sociais \& Humanas, alegando o alto custo e a baixa produtividade nas universidades públicas. A estratégia política de desmonte dessas universidades significa o cerceamento da liberdade de pensar como garantia da corporificação do conhecimento nas máquinas do capital, fazendo-o rolar na esteira de sua (re)produção.

Diante dessa disposição de selar e controlar o conhecimento científico, o governo terraplanista se depara com uma das maiores crises da humanidade, uma pandemia (Novo Coronavírus - COVID-19) que vai demandar mais e mais conhecimento científico, seja das ciências exatas, médicas e das humanidades. O desafio imediato é salvar vidas, garantir, sob a autoridade do conhecimento científico, a permanência da espécie humana aqui na Terra. E essa permanência implica não apenas lutar pela boa saúde física e mental, mas exigir a necessária saúde social, recusando a ingerência dos nossos corpos às amarras jurídicas do Estado e reafirmando o nosso livre exercício do cuidado de si, o que transformará a relação que estabelecemos com o saber, com os outros e com nós mesmos. Toda essa compreensão passa longe desse governo conservador e de ultradireita, seu comportamento, que tem indignado os dirigentes globais, demonstra o desprezo pela Ciência e pela população socialmente vulnerável.

Na contramão desse governo, a revista Cadernos de Gênero e Diversidade lança esse novo número com a intensão resistente (e desobediente) de estimular e produzir conhecimentos científicos. Lembrando que, diante dessa tragédia que vai ceifar vidas aos milhares, 
que tem nos lançado na mais estranha incerteza sobre o futuro, o saber é o caminho ético e estético para resgatarmos o cuidado por nós mesmos, para exercitarmos a solidariedade pelo outro e para retomarmos o amor ao mundo.

Esse número está composto por quatro artigos científicos, três ensaios, uma entrevista, um dossiê e duas resenhas. Os artigos são de temas variados, que abordam as questões LGBT no mundo sindical, a visão jurídica sobre as identidades trans, a antropologia feminista e a violência que acomete mulheres negras na atenção à saúde. Além desses, os ensaios trazem uma visão crítica sobre o aborto na América Latina, a reflexão sobre gays de direita e o papel da literatura na resistência LGBT. Já as resenhas, de livros atuais, abordam obras que tratam das mulheres na ciência e do conceito feminista de interseccionalidade.

Fazemos uma homenagem ao ativista João W. Nery na entrevista desse número. Feita em 2013 e intitulada Acerto de Pessoa, o arquivo foi editado e apresentado pelos estudantes de graduação Dhan Tripodi (UFBA) e Maria Luiza de Oliveira (UFS). Ao (re)descobrirmos a transcrição dessa entrevista em nossos arquivos e em razão do primeiro ano de sua morte, decidimos retomar o pensamento desse transhomem pioneiro, que tanto contribuiu com os direitos de cidadania de pessoas trans e LGBTQI+ em nosso país. Para ilustrar a entrevista contamos com uma linda pintura original do artista soteropolitano Dante Freire, cuja obra pode ser acessada em seu perfil na rede social Instagram (@inf3rnin). A entrevista é a nossa forma de demonstrarmos admiração, mas principalmente de compartilharmos nossa saudade e dor.

Já Miriam Grossi e Alexandra Alencar, organizadoras do dossiê Direitos Humanos, Antropologia e Educação: revisitando o passado e avançando na caminhada por uma educação anti-discriminatória, reuniram artigos com resultados do projeto Direitos Humanos, Antropologia, Educação: experiências de formação em Gênero e Diversidades. Nos artigos apresentados adentramos no papel das universidades públicas na promoção de uma educação justa e libertária para todos e todas. Os artigos avaliam uma série de políticas e ações da Universidade Federal de Santa Catarina que variam da execução das políticas do Nome Social para pessoas trans, a formação de professoras e professores em gênero e diversidade, as oficinas sobre gênero e sexualidades em escolas e também em comunidades indígenas e quilombola, e também como ocorreu a implementação do curso de graduação da Licenciatura Intercultural Indígena na instituição. Desta 
forma, o dossiê nos mostra que, num passado bem recente, o Brasil se encontrava na esteira de sua democratização com desejo de ampliar a justiça social e seus índices de igualdade, processo interrompido por um governo que, como dissemos acima, despreza os mais pobres desse país, que deveriam ser a prioridade de quaisquer gestores comprometidos com o nosso desenvolvimento.

A capa desta edição foi cedida pela artista equatoriana María José Machado Arévalo. Pepa, como é carinhosamente conhecida, é advogada, feminista, trabalhou em políticas públicas sobre gênero, direitos humanos e dissidência sexual. Faz parte do movimento de mulheres do Equador e movimento de artistas visuais. A partir dos vinte anos aprendeu com seu avô a pintar e o faz espontaneamente, inspirada em seu mundo interior ou no cotidiano e na subjetividade das mulheres e suas lutas. A artista nos conta que esta obra, que se chama Juntas, foi confeccionada em uma noite em que ela sentiu um pouco de tristeza. Decidiu desenhar rostos em alguns cartões que guardava das coleções de brinquedos que vêm com os jornais. Então todos os rostos nos desenhos refletiam essa nostalgia. Depois de alguns dias ela voltou a trabalhar e desenhou sorrisos nos rostos. E eles estavam lindos!

A artista refletiu sobre o por que de pintá-los isolados, por que cada um em um compartimento? E entendeu que é assim que o patriarcado nos quer. Como diria Coral Herrera, isolados, sozinhos, em lutas ridículas por sentimentos, em ninhos de amor individuais, carentes de sentimentos e isoladas da amizade, da participação e organização política. O próximo passo foi ligá-las. Além de descobrir os sorrisos, de pintá-las com cores alegres, de adquirir um corpo, as mãos e braços ligados seria a marca de uma união ancestral. Esse vínculo que as mulheres têm, em nossa diversidade, por causa da condição do nosso sexo/gênero. Que somos tão diferentes, mas que temos a mesma chance de viver a discriminação e a violência, com perigo adicional para as mulheres que sofrem maiores opressões dependendo da idade, raça, etnia, orientação sexual, posição econômica, política, origem, deficiências...

Na organização deste número da revista, aprendemos muito com os textos, com a entrevista, o dossiê e os artistas que conosco contribuíram. Estamos passando por um período histórico que está adoecendo pessoas sensíveis às questões sociais mais urgentes, sobretudo, as desigualdades e suas consequências. Para a nossa geração, este é um tempo que gera dúvidas, angústias e demandas variadas para 
suprir as nossas necessidades materiais e emocionais. Apesar do isolamento, também estamos vinculados em redes de apoio. Não são poucos os profissionais que estão disponibilizando, em redes sociais, serviços voluntários voltados à saúde mental; há também aqueles/as que mobilizam campanhas para arrecadar alimentos, remédios, máscaras e outros insumos. Existe a percepção de que é necessário cuidarmos dos outros/as e de nós mesmos/as, porque estamos adoecendo com toda a configuração política que vivenciamos.

Estamos diante, portanto, de um desafio científico, social e político, que tem colocado em xeque o nosso modo de vida, que tem nos feito pensar sobre a nossa condição humana e o sentido da nossa existência aqui na Terra. E principalmente, tem revelado as mazelas do sistema capitalista e a fragilidade das instituições políticas. Estávamos mesmo precisando dessa pausa, precisando refletir sobre o nosso futuro e da espécie humana. Agora, confinados em casa para proteger a nós e o outro do inimigo invisível, vivemos muitas dificuldades para administrar essa nova realidade, mesmo sabendo que esse perigo vai findar. Mas esse talvez seja um outro problema: como será a nossa vida pós-pandemia do coronavírus? A pandemia tem o efeito simbólico de espelhar uma imagem de nós que não tínhamos tempo de olhar e nos era imperceptível, e, se sairemos imunes desse vírus, não sairemos imunes dessa percepção de si. Agora vamos recomeçar a vida cotidiana, a nossa rotina, levando em nós esse sentimento de responsabilidade ética e humanidade, seja pelo planeta, pela sociedade e por nós mesmos.

É neste contexto que escrevemos este editorial, para refletirmos juntos/as sobre o corpo e o cuidado de si em época de pandemia e de isolamento social. Esperamos que essas leituras nos inspirem a pensarmos sobre a sociedade que construiremos para o futuro.

Boa leitura!

Mariângela Moreira NASCIMENTO

Felipe Bruno Martins FERNANDES Patrícia Rosalba Salvador Moura CosTA 